\title{
THE EFFECT OF PERCEIVED BUSINESS ETHICS ON BRAND PERSONALITY DIMENSIONS \& CREATION OF BRAND EQUITY IN DEVELOPING COUNTRIES
}

\author{
Hamidizadeh, M. R., Karimi Alavije, M. R., Rezaei, M.
}

Due to multi-dimension viewpoints, since decision-making and purchase process are emerging based on the human spirit or internal value of customers, this research seeks to introduce and analyze a model in this regard. In this research, the effects model of ethicality on brand personality dimensions and creation of brand equity were studied, aiming on raising awareness and highlighting the role of ethical values in branding. The population includes all the customers within Iranian chain stores (as a developing country). The results show that "perceived business ethicality" has a positive effect on responsibility, activity and emotionality. Moreover, responsibility and activity have a positive effect on "overall brand equity”. According to total effect, „responsibility“ and „perceived business ethicality" have the highest effect on brand equity.

JEL Classification: M31, D22, D63

Keywords: Perceived business ethicality (PBE); brand personality dimensions; overall brand equity; partial least squares structural equation modeling (PLS-SEM); chain stories

\section{Introduction}

In recent years, increasing concerns about business ethics issues makes businesses face them more seriously (Singhapakdi et al., 2007). On the other hand, ,the downturn led to a tripling of the country's unemployment rate" and it has imposed enormous costs on society (Biktimirov et al., 2012). Also, since the competitive environment of business is becoming more severe day-by-day, businesses cannot solely focus on concepts like Product and Brand; on the contrary, commercial businesses should focus on their customers and provide their values and wishes to succeed in this market. In spite of the fact that many researchers have emphasized the importance of the customer, few businesses have paid attention to it (Kotler, 2005). In recent years, a new approach is emerging called ,from products to customers to the human spirit" (Kotler et al., 2010). They stated that customers were like a full human with a mind, heart and soul; and the human spirit referred to the moral values. Hence, commercial businesses require much effort to identify, adjust and provide beneficiaries' values in the business process. Therefore, it can be clearly stated that providing values will have a direct connection with decision making and the purchasing process of actual and potential customers. From the 1990s, various research has been written in the field of ethics and corporate social responsibility values (Wilkie et al., 2012); but there has been no research considering the role of moral values in strengthening the brand personality dimensions and creating brand equity. Moreover, in spite of the fact that ethical issues have been discussed widely during the past decades by researchers, the evidence shows that unethical behavior still exists in great amounts in marketing activities (Abela et al., 2008).

Ethical business practices, along with the expectations of beneficiaries, affect the consumers' behaviors as well as creating a good image, reputation and value of the businesses in the minds of customers (Bendixen et al., 2007) and also, they reinforce their business personality. Moreover, brand personality has a major role in

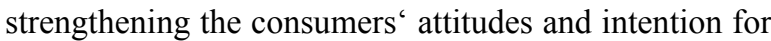
purchasing (Freling et al., 2011).

Today, businesses require many efforts for creating value, image and good reputation in the minds of customers in order to create a good image; thus they will be able to create more value for the customers and ultimately for 
the business. Moreover, a business can create value for its customer if it provides maximum customer demands; meanwhile, ethics are currently one of the most important customer demands. When a company observes ethics, it impacts customers" perceptions and they will see the company as a responsible business toward the society, and this will reinforce the company's brand personality. Thus, considering the competitive conditions, technological development and globalization, businesses are not able to achieve success only by relying on the product and the brand; rather they should also pay attention to the expectations and demands of the customers. Therefore, those brands can create advantages for the businesses which comply with customers' demands and expectations. When there is consistency between the business and the consumer's expectations, it is considered that the business has a good personality. So, branding will be good when it will be able to coordinate the customer's perceptions with the product/brand/ company.

A desired brand personality is used for reinforcing the consumer preferences, increasing the feelings of the consumer, increasing trust and loyalty, encouraging the consumer's emotion and providing a basis for distinguishing between products (Freling et al., 2005); it is concluded that the brand personality strengthens the consumer-brand relationship, which means it creates brand equity. Thus, compatibility of personalities of the brand and the customer results in relatively stable behavior in consumer purchasing.

Today, chain stores are one of the most dynamic businesses in metropolitan areas, which are under great competitive pressure. They need special attention from their managers for creating and keeping the competitive rank and advantages in the market. Chain stores are known as service stores with appropriate price (because of whole and direct purchase from the manufacturer without any dealers) and easy access for customers, which are related competitive advantages compared to other sellers or retailers. In recent years, in the city of Tehran, on one hand, comparing to older stores like Iranian chain stores, the incoming stores have been able to find very good status; on the other hand, since the stores have never lost their position in the market, and they even continue to grow and allocate more share in the market itself, they need to implement strategies to create a competitive advantage over the long-term. And as the company's most important asset, they need to achieve a stable relationship with their customers. This research intends to examine Iranian chain stores which were established in 1994, and currently have 24 branches in the city of Tehran. It seems that the Iranian chain stores (like other chain stores in developing countries) should reinforce their brand personality through providing expectations of beneficiaries, such as observing ethical attributes in order to achieve a long-term strategy for keeping their customers, which is the goal of branding by emphasizing the customer needs and values; they should reinforce them. This study deals with the issue of lack of knowledge and understanding of stores managers about the ethical attributes and their effects on brand personality dimensions and creation of brand equity in chain stores of Iran as a developing country. Thus, this research primarily intends to examine theoretical and practical studies on this issue, and highlight the role of ethical attributes in branding, specially brand personality, and decrease the lack of awareness; it means that, in the first step, the study examines the relationship and effects of perceived business ethicality on brand personality dimensions. Then, it will examine the role of perceived business ethicality and its importance on creating brand equity; Moreover, the relation and effect of ethical attributes on each dimension of brand personality, and the relation and effect of brand personality on special brand value will be studied.

\section{Research Objectives}

A. To investigate the demographic data analysis of customers;

B. To investigate the relationship between business ethical attributes and brand personality dimensions;

C. To investigate the relationship between brand personality dimensions and brand equity;

D. To explain the whole effects of brand equity.

\section{Literature Review}

In recent years, research in the field of the consumer's perception from ethical practices and the corporate social responsibility of the company and its impact on the business performance have been developed, because of its competitive advantage by ethical values (Chabowski et al., 2011). Hence, Labrecque and Milne (2012) state that ,strong, positive brand personalities can enhance consumer evaluations and increase brand equity“. „Brands need to find a way to communicate a relevant set of values to their consumers" (Singh et al., 2012); hence, the ethical brand includes attributes such as honesty, integrity, diversity, responsibility, quality, respect and accountability (Singh et al., 2012). Aaker (1997) in her article titled "Dimensions of Brand Personality" says that ethical attributes have a positive effect on the two dimensions of "sincerity" and 
"competence". Also, Fournier (1998) suggests that all policies and practices that are applied by businesses to the marketing mix can be seen as a set of brand behaviors that can affect the brand personality; also, he stresses that brands can have thoughts or feelings through the daily activities of marketers (Jean-Ruel, 2008). Craft (2012) examined the literature of ethics from 2004 to 2011; his research shows that little research has been done on the relationship between ethics and personality dimensions. For the first time, Jean-Ruel (2008) examined the direct effect of ethical attributes of business on dimensions of brand personality; she discovered that perceived ethical attributes have a positive effect on "competence“, „excitement", "sophistication" and much more on „sincerity“. In this study, perceived business ethical attributes are defined as: ,attributes that reflect a person's conscience“" (Jean-Ruel, 2008).

In addition, Bouhlel et al. (2011) believe that brand personality distinguishes the brand from its competitors, and in the results, brand equity will be created and improved, because brand personality is one of the main dimensions of brand equity; in addition, brand personality is able to improve brand trust, brand dependency and consumer-brand relationships. Also, Supphellen and Grønhaug (2003) note that many researchers have paid attention to the concept of brand personality that was introduced by Aaker (1997), because it is an important concept for making distinction as well as long-term development of brand equity. Thus, brand personality is an important factor for the success of businesses, since a unique brand personality helps to create a set of appropriate and unique links in the minds of customers, which lead to brand equity (Keller, 2003). Also, McCorkindale (2008), Valette-Florence et al. (2011) and Folse et al. (2012) have concluded that brand personality has a significant positive effect on brand equity.

\section{Methodology}

The research analyzes the creation of brand equity based on Iranian chain stores in Tehran city in Iran as a developing country; thus it is applied research considering its aim and it is descriptive and correlative surveying research considering the data collection.

\subsection{Research Model and Variables}

The research has seven variables (one independent variable, five mediator variables and one dependent variable). Perceived business ethicality (=PBE) is an independent variable, brand personality dimensions (responsibility, activity, emotionality, simplicity and aggressiveness) are mediator variables, and overall brand equity is the dependent variable.

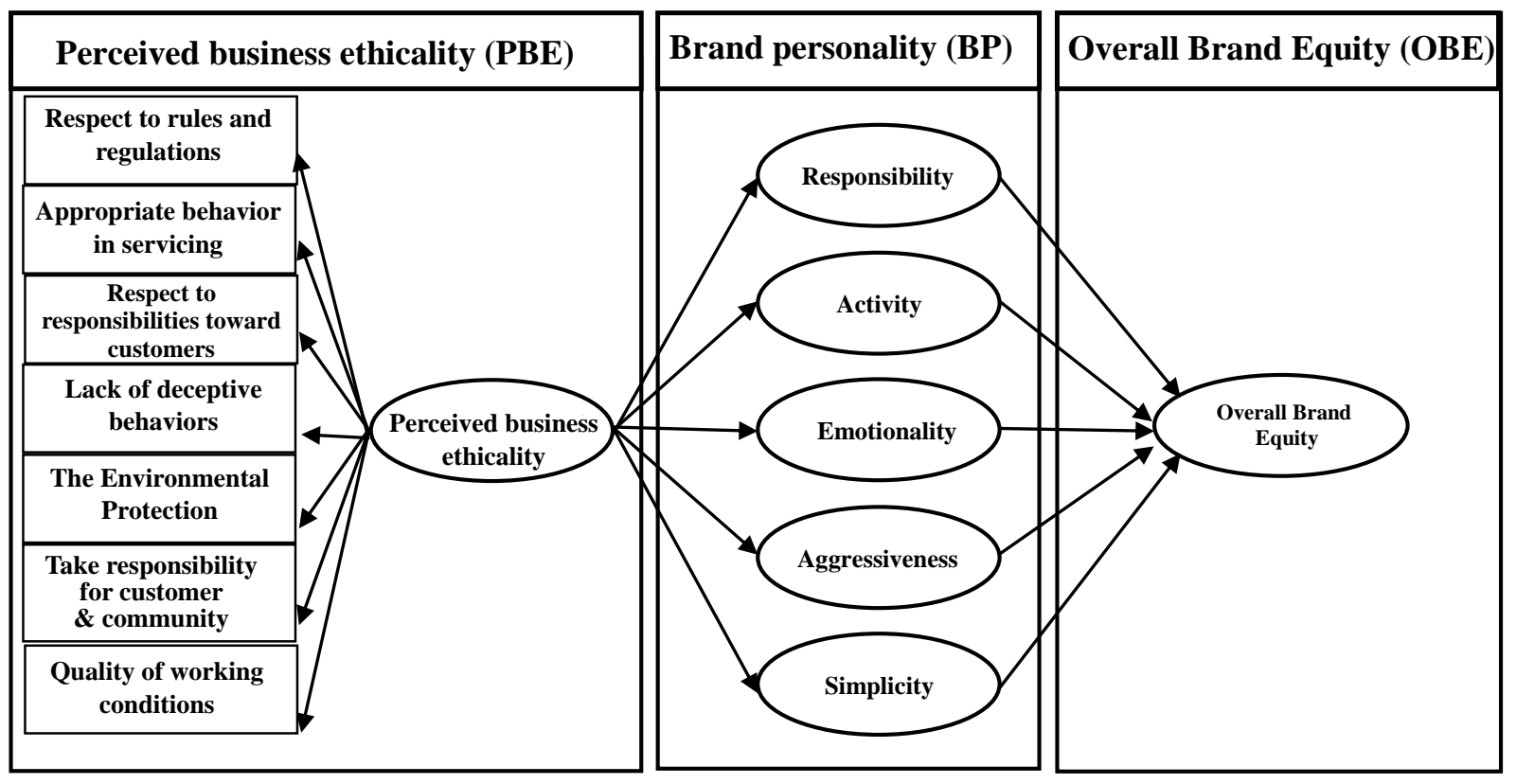


Table 1 Research main and secondary hypotheses

$\mathrm{H}_{1}$ : Brand personality has a positive relationship with business ethical attributes.

The Secondary hypotheses

\begin{tabular}{|l|}
$\mathrm{H}_{1 \mathrm{a}}:$ Responsibility has a positive relationship with business ethical attributes. \\
\hline $\mathrm{H}_{1 \mathrm{~b}}:$ Activity has a positive relationship with business ethical attributes. \\
\hline $\mathrm{H}_{1 \mathrm{c}}:$ Emotionality has a positive relationship with business ethical attributes. \\
\hline $\mathrm{H}_{1 \mathrm{~d}}:$ Aggressiveness has a positive relationship with business ethical attributes. \\
\hline $\mathrm{H}_{1 \mathrm{e}}:$ Simplicity has a positive relationship with business ethical attributes. \\
\hline
\end{tabular}

$\mathrm{H}_{2}$ : Brand equity has a positive relationship with brand personality.

The Secondary hypotheses

\begin{tabular}{|l|}
$\mathrm{H}_{2 \mathrm{a}}:$ Brand equity has a positive relationship with responsibility. \\
\hline $\mathrm{H}_{2 \mathrm{~b}}$ : Brand equity has a positive relationship with activity. \\
\hline $\mathrm{H}_{2 \mathrm{c}}:$ Brand equity has a positive relationship with emotionality. \\
\hline $\mathrm{H}_{2 \mathrm{e}}:$ Brand equity has a positive relationship with aggressiveness. \\
\hline $\mathrm{H}_{2 \mathrm{~d}}:$ Brand equity has a positive relationship with simplicity. \\
\hline
\end{tabular}

Table 2 Final reliability of research variables

\begin{tabular}{|c|c|c|c|c|c|c|}
\hline \multicolumn{2}{|c|}{ Latent variables } & $\begin{array}{l}\text { Number of } \\
\text { Questions }\end{array}$ & $\begin{array}{c}\text { Cranach's } \\
\text { Alpha }\end{array}$ & AVE & CR & Reference \\
\hline \multicolumn{2}{|c|}{ Perceived Business Ethicality } & 7 & 0.87 & 0.56 & 0.9 & Leonidas et al. (2012) \\
\hline \multirow[t]{5}{*}{ Brand personality } & Responsibility & 3 & 0.73 & 0.65 & 0.84 & \multirow[t]{5}{*}{ Geuens et al. (2009) } \\
\hline & Activity & 3 & 0.80 & 0.72 & 0.86 & \\
\hline & Emotionality & 2 & 0.848 & 0.86 & 0.92 & \\
\hline & Aggressiveness $^{*}$ & 2 & -0.007 & 0.5 & 0.34 & \\
\hline & Simplicity ${ }^{* 1}$ & 2 & 0.60 & 0.33 & 0.19 & \\
\hline \multicolumn{2}{|l|}{ Overall brand equity } & 4 & 0.87 & 0.69 & 0.89 & Washburn et al. (2002) \\
\hline
\end{tabular}

1 Varaibles are shown with * was Removed from the tested model

\subsection{Measurement and Gathering Data}

The references of latent variables measures are shown in table 2. In this study, data was collected by a standard questionnaire consisting of a 5-points Likert ranging from "1: totally disagree" to "5: totally agree". They are collected through a self-reported questionnaire over a six week period; complete information was collected from 395 customers in the chain store.

\subsection{Reliability and Validity}

Cronbach's alpha more than 0.7 , composite reliability (CR) more than 0.6 and Average Variance Extracted (AVE) more than 0.5 are used for evaluating the reliability of the variables (Hamidizade et al., 2012) (Table 2). Of course, by analyzing the reliability indices, it is indicated that all variables, except for two dimensions of brand personality (aggressiveness and simplicity), have good reliability. Therefore, for achieving good reliability in brand personality, indices with a load factor less than an absolute value of 0.5 are removed. And since, the Cronbach's alpha of aggressiveness $\&$ simplicity do not improve, so they are removed.

\subsection{Population and Sample Size}

The research population includes all customers of 24 branches of the Iranian chain stores in Tehran city. Considering the fact that the population size is unknown, based on Krejcie and Morgan table (1970) the sample size could be 384 customers. Therefore, at first, we have classified stores into five regions (North, South, Center, East and West) and in each region 75 samples (384 divided by 5) should be collected. This classification is done for considering cultural differences of various regions. Then, 75 samples are divided by the number of stores in each region and also, the cluster sampling procedure is followed. 
Figure 2 Tested model (T-value $>|1.96|)$

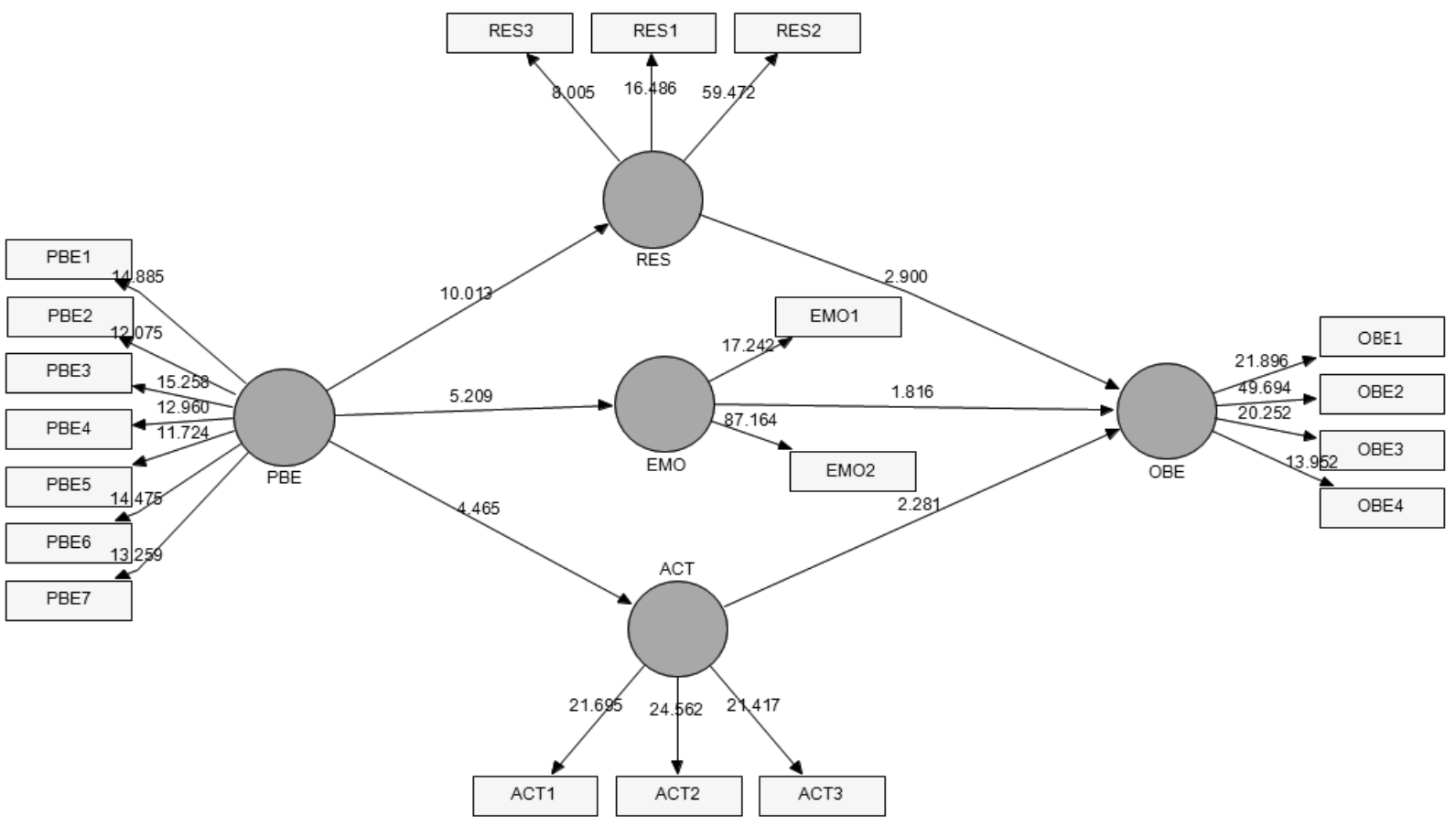

Figure 3 Tested model ( $R^{2}, \beta$ and factor loading)

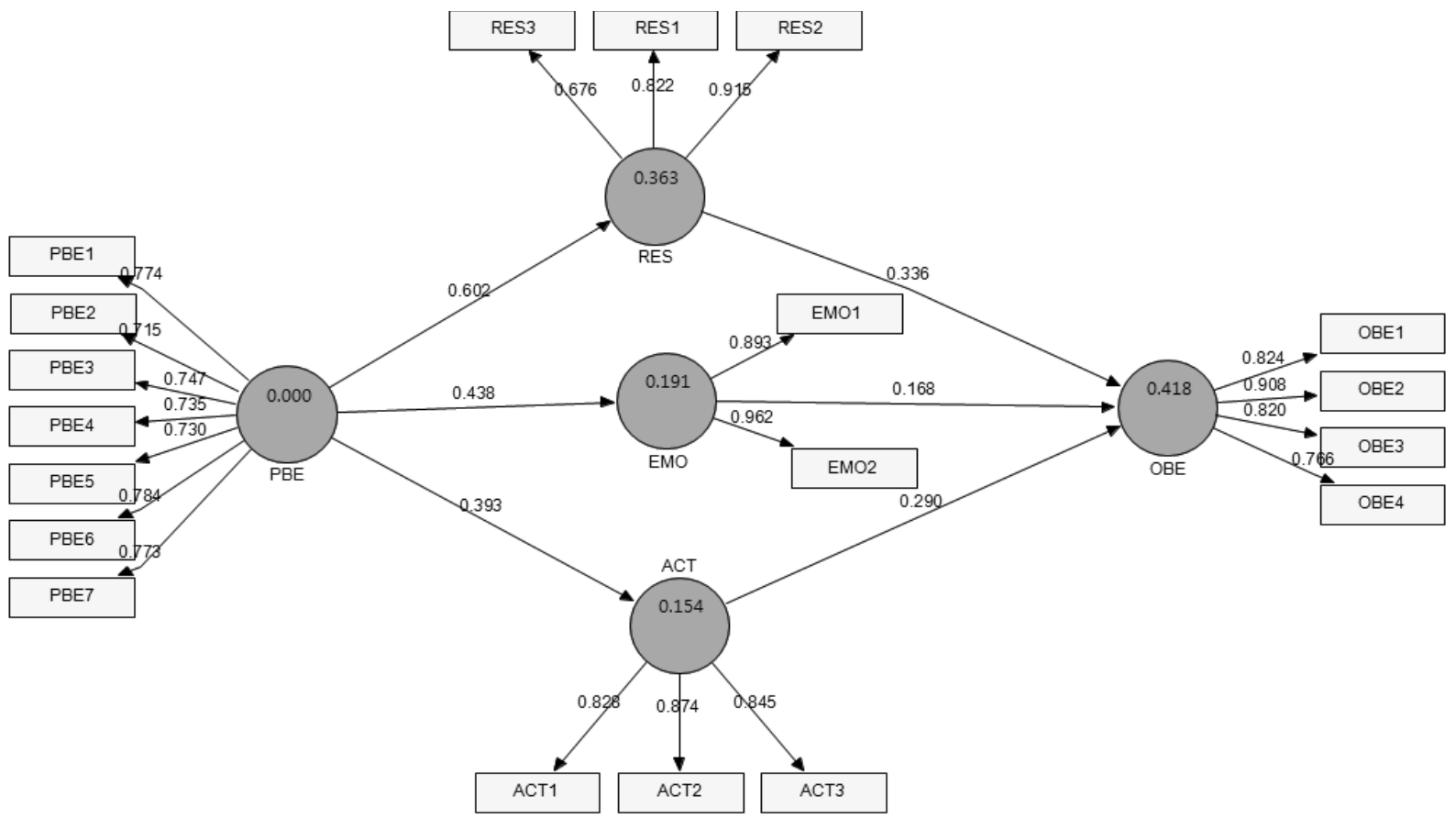




\section{Statistical Analysis of Data}

\subsection{Demographic Sample Analysis}

Statistical analysis shows that the majority of respondents are men $(56.7 \%)$ and married $(87.13 \%)$. Also, most of the respondents are between 30 and 40 years old for men $(22.03 \%)$, and under 30 years old in women $(17.72 \%)$. But, $38.49 \%$ of respondents were between 30 and 40 years of age. Half of the respondents (49\%) have a bachelor's degree. This is consistent in each of the groups of men and women. Most of the respondents (36\%) have income between 7 to 9 million Rails. More than $75 \%$ of the respondents did their shopping more than once per month.

\subsection{Conceptual Model and Hypotheses Test}

"Our review shows that PLS-SEM's methodological properties are widely misunderstood, at times leading to the technique's misapplication, even in top tier journals" (Hair et al., 2012). Moreover, researchers should consider the PLS-SEM's methodological foundations and complementary analysis techniques more strongly. So, Smart-pls2.0 software is used for testing the conceptual model and hypotheses. The structural model is presented in Figure 3. In this graph, the acronyms of PBE, RES, ACT, EMO and OBE represent respectively Perceived Business Ethicality, Responsibility, Activity, Emotionality and Overall Brand Equity. All paths had a t-value higher than the standard rate of absolute value of 1.96, apart from the relationship between Emotionality and Overall Brand Equity; and the results show significant and positive relationships between variables (Table 3 ).

Moreover, the measurement model is presented in Figure 3. The numbers inside the circles are coefficients of determination $\left(\mathrm{R}^{2}\right)$ and the numbers above the arrows are the path coefficient $(\beta)$. Of course, the numbers above the arrows toward observed variables represent factor loadings, all of them have an appropriate amount (greater than 0.5).

Table 3 Testing model hypothesis results

\begin{tabular}{|l|c|c|}
\hline Path & T-value & Hypothesis \\
\hline $\mathrm{PBE} \rightarrow \mathrm{RES}$ & 10.013 & Supported \\
\hline $\mathrm{PBE} \rightarrow \mathrm{ACT}$ & 4.465 & Supported \\
\hline $\mathrm{PBE} \rightarrow \mathrm{EMO}$ & 5.209 & Supported \\
\hline $\mathrm{RES} \rightarrow \mathrm{OBE}$ & 2.900 & Supported \\
\hline $\mathrm{ACT} \rightarrow \mathrm{OBE}$ & 2.281 & Supported \\
\hline $\mathrm{EMO} \rightarrow \mathrm{OBE}$ & 1.816 & Unsupported \\
\hline
\end{tabular}

\subsection{Total, Direct and Indirect Effects}

As shown in Table 4, responsibility has the greatest total effect (0.336) on overall brand equity among the variables; this effect is direct. The second effective variable is perceived business ethicality (0.314) and finally, the third effective variable is activity which has only a direct effect $(0.29)$ on overall brand equity.

\section{Conclusion and Managerial Implications}

Considering the ever-increasing importance of ethical attributes in businesses, this research intends to highlight the role of ethics in branding and creating brand equity for businesses and chain stores in Iran. This research had two main hypotheses and ten sub-hypotheses, five of which discuss the relationship between perceived business ethicality and personality dimensions; the other five hypotheses discuss the relationship between personality dimensions and brand equity. The results show that perceived business ethical attributes have a positive effect on three dimensions of responsibility, activity and emotionality. Furthermore, both responsibility and activity have significant and positive effects on brand

Table 4 Total effects of PBE on OBE

\begin{tabular}{|l|c|c|c|c|}
\hline \multirow{2}{*}{$\begin{array}{l}\text { Dependent } \\
\text { variables }\end{array}$} & \multirow{2}{*}{$\begin{array}{l}\text { Independent } \\
\text { variables }\end{array}$} & \multicolumn{3}{|c|}{ Effect } \\
\cline { 3 - 5 } & & Direct & Indirect & Total \\
\hline $\begin{array}{l}\text { Overall Brand } \\
\text { Equity }\end{array}$ & PBE & -- & $(0.602 \times 0.336)+(0.393 \times 0.290)=0.314$ & 0.314 \\
\cline { 2 - 5 } & RES & 0.336 & -- & 0.336 \\
\cline { 2 - 5 } & ACT & 0.29 & -- & 0.29 \\
\hline Responsibility & PBE & 0.602 & -- & 0.602 \\
\hline Activity & PBE & 0.393 & -- & 0.393 \\
\hline Emotionality & PBE & 0.438 & -- & 0.438 \\
\hline
\end{tabular}


equity. Among previous studies, only one has evaluated the relationship between ethical attributes and brand personality dimensions, but it has applied indices of Aaker (1997) for examining the relationships; since this study has used the indices of Geuens et al. (2009), the results of this research cannot be compared with other research. Moreover, the previous studies have examined the relationship between personality dimensions and brand equity in general and have not analyzed the effects of personality dimensions on equity. Current conditions (figure 2) of the Iranian chain stores confirm that they should enhance competitive advantages by PBE. So, other chain store administrators should pay more attention to and enhance brand personality by "perceived business ethicality" for creation of equity. In figure 3, factors loading show that the "responsibility for customer and community" (the sixth index) had the highest impact in the "perceived business ethicality" variable; of course, other indices are more important, because their factor loadings are more than 0.7 ; similar to them are "the responsible" index in the responsibility variable; "the sentimental" (the second index) in the emotionality variable; "dynamic" (the second index) in the activity variable; and finally, customers say "Even if there is another as good as this brand, they still prefer to buy this brand". Also, the results show that responsibility and perceived business ethicality have the greatest total direct and indirect effects on brand equity. Therefore, administrators can strengthen the brand personality by ethical attributes and finally, they can create equity for the business. Based on the results, because of increasing competition in business in developing countries, firms must differentiate themselves from other competitors. Through ethics, firms are able to create a competitive advantage, increase brand equity, and display their social responsibility to customers. Furthermore by ethical features, firms and chain stores can attract more customers and make them loyal; they can also strengthen their market share as well as positive word of mouth advertising and ensure their survival.

\section{References}

Aaker, J. (1997). Dimensions of Brand Personality. Journal of Marketing Research, 34: 347-356.

Abela, V. A., Murphy, P. E. (2008). Marketing with Integrity: Ethics and the Service Dominant Logic for Marketing. Journal of the Academy of Marketing Science, 36: 39-53.

Bendixen, M., Abratt, R. (2007). Corporate Identity, Ethics and Reputation in Supplier- Buyer Relationships. Journal of Business Ethics, 76: 69-82.
Biktimirov, E.N., Cyr, D. (2012). Using Inside Job to Teach Business Ethics, (accessed October 20, 2012), [available at http://link.springer.com/article /10.1007 /s10551-0121516-y/fulltext.html].

Bouhlel, O., Mzoughi, N., Hadiji., D., Slimane, I.B. (2011). Brand Personality's Influence on the Purchase Intention: A Mobile Marketing Case. International Journal of Business and Management, 6 (9): 210-227.

Chabowski, B. R., Mena, J. A., Gonzalez-Padron, T. L. (2011). The Structure of Sustainability Research in Marketing, 1958-2008: A Basis for Future Research Opportunities. Journal of the Academy of Marketing Science, 39: 55-70.

Craft, J. L. (2012). A Review of the Empirical Ethical Decision-Making Literature: 2004-2011, (accessed October20, 2012), [available at http://link.springer.com/ article/10.1007 /s10551-012-1518-9].

Folse, J. A. G., Netemeyer, R.G., Burton, S. (2012). How the Personality Traits of Sincerity: Excitement: and Competence Help to Build Equity. Journal of Advertising: 41 (1): 17-32.

Fournier, S. (1998). Consumers and Their Brands: Developing Relationship Theory in Consumer Research. Journal of Consumer Research, 24: 343-373.

Freling, T. H., Forbes, L. P. (2005). An Empirical Analysis of the Brand Personality Effect. Journal of Product \& Brand Management, 14 (7): $404-413$.

Freling, T. H., Crosno, J. L., Henard, D. H. (2011). Brand Personality Appeal: Conceptualization and Empirical Validation. Journal of Business Ethics, 39: 392-406.

Geuens, M., Weijters, B., Wulf, K.D. (2009). A New Measure of Brand Personality. International Journal of Research in Marketing, 26: 97-107.

Hair, J. F., Sarstedt, M., Ringle, C. M., Mena, J. A. (2012). An Assessment of the Use of Partial Least Squares Structural Equation Modeling in Marketing Research. Journal of the Academy of Marketing Science, 40: 414-433.

Hamidizadeh, M.R., karimi alavije, M.R., rezaee, M. (2012). The examination of relationships between personality dimensions \& Brand Equity and moderator role of Ethical Attributes. New Marketing Research, 2 (3): 35-50.

Jean-Ruel, E. (2008). The Effect of Ethical Attributes on Brand Personality and Consumer-Brand Relationships (Master dissertation), (accessed October 20, 2012), [available at http://www.collectionscanada.gc.ca/obj/ thesescanada/vol2/002/MR45302.PDF].

Keller, K. L. (2003). Strategic Brand Management: Building, Measuring and Managing Brand Equity (2nd ed). Upper Saddle River, NJ: Prentice Hall. 
Kotler, P. (2005). According to Kotler. New York: Amacom.

Kotler, P., Setiawan, I., Kartajaya, H. (2010). Marketing 3.0: From Products to Customers to the Human Spirit, Danesh Ofogh Publication, translated by: Ebrahimi, A., AAli, S., zende, A.B., \& Ashrafi, E.A., Industrial Management Organization in Tabriz city of Iran (2011), pp. 22-24.

Labrecque, L. I., Milne, G. R. (2012). Exciting Red and Competent Blue: the Importance of Color in Marketing. Journal of the Academy of Marketing Science, 40: 711-727.

Lee, H., Kang, M. S. (2010). The Impact of Brand Transgressions on Relationship Strength: Moderating Roles of Brand Personality and Consumer Loss Type. Proceedings of the Academy of Marketing Studies, 15 (1): 29-35.

Leonidas, C. L., Kvasova, O., Leonidou, C. N., Chari, S. (2012). Business Unethicality as an Impediment to Consumer Trust: The Moderating Role of Demographic and Cultural Characteristics, (accessed October 20, 2012), [available at: http://link.springer.com/content/pdf /10.1007\%2Fs10551-012-1267-9].

McCorkindale, T. (2008). Does Familiarity Breed Contempt? Analyses of the Relationship among Company Familiarity, Company Reputation, Company Citizenship, and Company Personality on Corporate Equity. Public Relations Review, 34: 392-395.

Purkayastha, S. (2009). Brand Personality: An Empirical Study of Four Brands in India. The IUP Journal of Management Research, 8 (4): 7-20.

Singh, J. J., Iglesias, O., Batista-Foguet, J. M. (2012). Does Having an Ethical Brand Matter? The Influence of Consumer Perceived Ethicality on Trust, Affect and Loyalty. Journal of Business Ethics, (accessed October 20, 2012), [available at: http://rd.springer.com/article /10.1007/s10551-012-1216-7].

Singhapakdi, A., Vitell, S. J. (2007). Institutionalization of Ethics and Its Consequences: A Survey of Marketing Professionals. Journal of the Academy of Marketing Science, 35: 284-294.
Supphellen, M. Grønhaug, K. (2003). "Building foreign brand personalities in Russia: the moderating effect of consumer ethnocentrism", International Journal of Advertising, 22: 203-26.

Valette-Florence, P., Guizani, H., Merunka, D. (2011). The Impact of Brand Personality and Sales Promotions on Brand Equity. Journal of Business Research, 64: 24-28.

Washburn, J. H., Plank, R. E. (2002). Measuring Brand Equity: And evaluation of a Consumer-Based Brand Equity Scale. Journal of Marketing Theory and Practice, winter: 46-61.

Wilkie, W. L., Moore, E. S. (2012). Expanding our Understanding of Marketing in Society. Journal of the Academy of Marketing Science, 40: 53-73.

\section{Mohammad Reza Hamidizadeh \\ Full Professor}

Management and Accounting Faculty Shahid Beheshti University, Tehran, Iran M-Hamidizadeh@sbu.ac.ir

Mohammad Reza karimi Alavije, Assistant Professor,

Management and Accounting Faculty Allameh Tabataba'i University, Tehran, Iran mr.karimi@atu.ac.ir

Morteza Rezaee

MBA, Management and Accounting Faculty Shahid Beheshti University, Tehran, Iran mr_1332@yahoo.com 